\title{
THE CHRISTIAN FAITH AS PREDICTOR OF LONELINESS
}

\author{
Anda le Roux \\ Free State University
}

\begin{abstract}
The chief aim of the research was to investigate the importance of Christian faith in the prediction of loneliness. Questionnaires were completed by more than 3000 church members of the reformed churches in Bloemfontein, from which a sample of 1000 questionnaires was randomly drawn in order to form the research sample. The results, generated by means of a stepwise multiple regression analysis, showed that faith in Jesus Christ is an important predictor in loneliness. It was also found that certain biographical variables correlate very highly with loneliness and can be used effectively to predict loneliness amongst individuals. This combination of variables, viz. Christian faith and biographical variables, managed to account for about $19 \%$ of the variance of loneliness.
\end{abstract}

\section{Introduction}

Man was not made to be alone, but was created for relationships (McGraw, 1992). The most important and deepest relationship that anyone could ever enter, is the vital relationship with God, our Creator, being reconciled with Him through faith in Jesus Christ, and having an intimate and personal relationship with Him. Only in perfect personal communion, that of religious communion with God through faith in Jesus Christ, can one come to full selfrealisation, in which the deepest self and self-worth are exposed (Couwenberg, 1959). Second to this is the horizontal dimension: our relationships with our fellow-beings. This concerns one's perception of the purpose and satisfaction of one's life (Moberg \& Brusek, 1978; Tozer, 1984). When these relationships fail, and the most important of all relationships, an intimate personal relationship with God through Jesus Christ, is lacking, the consequences for every individual could be serious. Loneliness would then be inevitable, resulting in emotional trauma of indeterminable proportions (MacArthur, 1991).

Despite the importance of the above mentioned premise it is interesting to note that certain aspects of human development receive noticeably more attention from researchers than others (Le Roux, 1998; Le Roux \& De Beer, 1994). Topics, such as personality and intelligence, are investigated more often while emotional aspects, like loneliness in the individual, received relatively little attention. In the same way religious behaviour has received scant attention, and has been practically ignored by researchers and psychological practitioners for decades. The apparent reason for this seems to be that modern-day psychologists regard aspects of faith, such as devotion, witnessing, worship and spiritual seclusion, with suspicion, to the point of associating it with some form of psychiatric disorder or pathology (Clay, 1996; Le Roux, 1998). Jones (1994) is, however, of the opinion that if psychologists want to be maximally effective in understanding and improving human behaviour, it is of cardinal importance to investigate explicitly the deepest levels of human functioning. For this researcher, constructs such as loneliness and faith fall within this scope, and thus the current attempt to investigate further these specific dimensions of human behaviour.

The literature contains a wide variety of psychological definitions for loneliness. However, in all of these, two important aspects were universally present. Firstly, the source of loneliness can invariably be attributed to the development of poor social relationships, in which the basic needs of the individual are not satisfied. Secondly, the experience of 
loneliness is both unpleasant and painful, e.g. the painful longing for a level of interaction with people deeper than is presently possible. Sears, Peplau and Taylor (1991) accordingly state that loneliness refers to a subjective feeling of distress, which is experienced when social relationships lack a certain important quality. Peplau and Perlman (1982) and Sullivan (1953) showed that the unpleasant experience of loneliness results from a (qualitatively and/or quantitatively) poor network of social relationships. Ellison (1978) defined loneliness as a subjective psychological experience, encompassing cognitive, emotional, behavioural and motivational components, being characterised overall by an intensively negative emotional state. The fact that deficient social relationships can cause psychological discomfort led Young (1982) to the conclusion that these social relationships should be seen as a specific source of support for the individual. This means that loneliness is a result of the absence of important social support.

Various factors have already been investigated as possible causes in the determinance of loneliness. A multi-dimensional model for loneliness, consisting of five factors, was proposed by Rokach and Brock (1997). The primary cause they identified was emotional distress, accounting for $19 \%$ for the variance. Emotional need can include feelings of intense pain, inner turmoil, hopelessness and emptiness. The next predictor they identified was inadequacy and alienation. Included here are aspects such as poor observation skills and the social isolation accompanying these factors. The third factor was that of growth and discovery, meaning an enriching positive feeling of increasing inner strength. Fourth came the feelings of abandonment and rejection, resulting from either a lack of close relationships and/or the absence of a romantic relationship. The fifth factor is selfalienation, which can be defined as a detachment from the self. This is characterised by feelings of numbness, denial and immobilization. These last four factors together explained $17 \%$ of the variance of loneliness (Rokach \& Brock, 1997).

In a general model of the causes of loneliness Rokach and Brock (1996) reported five factors. The factor that emerged as the most salient was personal inadequacies (17\% of variance), which included items that addressed characteristics and/or experiences which resulted in low self-esteem, mistrust, fear or intimacy and feeling socially ill-at-ease. The second factor, developmental deficits ( $6 \%$ of variance), addressed the developmental and familial antecedents of adult loneliness such as growing up in an inadequate or dysfunctional home that is characterised by rejecting parents and/or psychological or physical abuse. In the third place was unfulfilling intimate relationships (5\% of variance), followed by relocation/significant separations which declared $4 \%$ of the variance of loneliness. The fifth factor was social marginality ( $4 \%$ of variance) which addressed the actual or perceived social rejection and distancing which criminals, the unemployed and the chronically ill commonly experience.

The set of emotional conditions individuals experience has been the main focus of investigations into loneliness for several years (De Beer, 1992; Ferns, 1991; Peplau \& Perlman, 1982; Scholtz, 1995; Weiss, 1973). According to these researchers emotional loneliness can result from either the absence and/or the severance of intimate emotional ties within some or all of the individual's relationships, or even by circumstantial changes within these relationships. Emotionally isolated individuals lack any intimate figure to whom they can turn to in times of crises, and this can result in separation anxiety (Weiss, 1989). These individuals also lack relationships with sufficient intimacy for them to share their deepest needs and longings. The desolation and rejection experienced by these individuals leads to feelings of emptiness and an intense longing for love and acceptance by others (Cruz, 1983). Based on this, high-risk groups for loneliness can be defined. These include the following (De Beer, 1992; Gaev, 1976; Odendal, 1985; Peplau \& Perlman, 1982; Rubenstein \& Shaver, 1982; Scholtz, 1995; Taylor, Peplau \& Sears, 1994): 
- Victims of traumatic childhood experiences. These include parental divorce or death, parental abuse and/or negative familial influences;

- $\quad$ Social outcasts, e.g. disabled individuals;

- Low socio-economic status. In modern society, time and money are often used for entertaining friends and building relationships;

- $\quad$ Divorce - it leads to emotional trauma and a loss of social relationships;

- Dysfunctional marriages - this includes marital conflict and unsatisfied needs;

- A whole gammet of personality factors may predispose an individual towards loneliness. These include suspicion, self-consciousness, shyness, feelings of guilt, feelings of low self-esteem, and an external locus of control (Cheek \& Busch, 1981; Diamant \& Windholz, 1981; Ferns, 1991; Hojat, 1982; Janse van Rensburg, 1991; Taylor et al., 1994). Individuals lacking self-confidence are less likely to feel at liberty to open and express their feelings (Hansson \& Jones, 1981). These individuals often feel worthless and are dissatisfied with themselves (Hojat, 1982; Peplau \& Perlman, 1982). Irritability is another trait (Rubenstein and Shaver, 1982) and also the negative evaluation of other individuals (Jones, Sansone \& Helm, 1983). According to Cutrona (1982); Diamant and Windholz (1981) and Moore (1972), submissiveness may also predispose an individual towards loneliness.

Another factor which needs to be investigated in any study on loneliness is the Christian faith, as many theologians and philosofers emphasize the religions basis of loneliness (Duvenhage, 1975; MacArthur, 1995; McGraw, 1992 and Sobosan, 1978. Duvenage (1975) stressed that although loneliness is concerned with deficient intimate relationships and unsatisfied needs, it cannot simply be explained horizontally. According to him the deepest problem with lonely people is their severance of the vertical relationship: that between a human being and God. This is parallel to Couwenberg's (1959) view that the root of the problem regarding man's loneliness is that of religious uprooting. He says that humankind has become estranged from the reason for its existence: God. Researchers such as Gaev (1976), Moberg and Brusek (1978), Paloutzian and Ellison (1982) and Zimbardo (1979) all agreed that the experience of a person's faith exerts a strong influence on that person's well-being and is directly related to loneliness. Moberg and Brusek (1978) defined spiritual health as consisting of two dimensions, a vertical dimension reflecting mankind's spiritual standing with God, and the horizontal dimension, relating to individuals' perception of the purpose and satisfaction of their lives, independent of religious references. Allport and Ross (1967) found that persons who had a strong personal relationship with God were less lonely than others. Their results also indicated that non-believers were more likely to experience a lack of moral support, thus being more inclined to loneliness. Similarly, Le Roux (1998) reported a highly significant negative correlation between loneliness and the Christian faith.

The literature regarding loneliness and gender is full of conflicting results. For example, many researchers outside of South Africa found that male students were more lonely than female students (Borys and Perlman, 1985; Dufton, 1984; Pontzetti, 1990; Solano et al., 1982; Quellet \& Joshi, 1986). South African researchers such as Pretorius (1993) and Janse van Rensburg (1991) have found similar results. The former study was conducted at the University of the Western Cape using 659 pre-graduate black students, and the latter among 442 white late adolescents all from East London.

In contrast to this, Medora and Woodward (1986), Sundberg (1988), and Woodward and Frank (1988) found that women were lonelier than men. Still, other researchers outside of South Africa could find no significant difference between the occurrence of loneliness 
amongst the different genders (Barretta et al, 1995; Brage, Meredith \& Woodward, 1993; Goldenberg \& Perlman, 1984; Moore \& Schultz, 1983; Williams \& Solano, 1983). Also in South Africa a number of researchers reported similar findings (De Beer 1992; Ferns, 1988; Le Roux, 1992; Scholtz, 1995).

The relationship between loneliness and age has also been researched by a number of South African researchers. Ferns (1988) completed a study amongst 294 early adults and found no significant differences between the three levels of the age variable regarding loneliness. Janse van Rensburg (1991) and Le Roux (1992) found a low occurrence of loneliness amongst white South African teenagers, while Scholtz (1995) also found a low occurrence of loneliness amongst black Vista students of Bloemfontein. Overseas studies found that loneliness occurs mostly amongst young adults (Medora \& Woodward, 1986; Bolea, 1986). The latter researcher, as well as Parlee (1979) discovered that the incidence of loneliness is very high amongst teenagers and children in their middle childhood years (Parlee reported a 79\% occurrence of loneliness). The findings of Natale (1986) and Moore and Schultz (1983) indicate that the elderly people, both in and out of old age homes and institutions, are also particularly susceptible to loneliness.

The relationship between loneliness and church attendance has apparently not yet been researched, and is not reported in the existing literature. Nevertheless, given the significant inverse relationship between loneliness and faith, as reported in a recent study by Le Roux (1998), the question has risen in this researcher's mind whether such a relationship does not exist.

For MacArthur (1995) prayer is like breathing and a vitally important desire of the heart for every true Christian believer. Lloyd-Jones (1979) described prayer as being the highest activity of the human soul, and also at the same time the ultimate test for anyone's true spiritual standard. Prayer is the standard by which people can measure the real condition of their spiritual lives as they examine themselves in private, when they are alone with God. MacArthur (1995) went on to say that even if people are rejected and abandoned by their family, friends, or even fellow believers, they know that their Heavenly Father will never leave them (Heb. 13:5). He also said prayer dispels loneliness, and God's presence is all a believer ever needs. For this reason, this researcher is examining the relationship between loneliness and prayer in this study.

As we can see, loneliness is a complex phenomenon, and as the millions of people currently experiencing the devastation and destruction of loneliness will testify, it is something against which nobody is immune. Loneliness is debilitating and demoralising, and robs life of quality and motivation (Ferns, 1991; Janse van Rensburg, 1991). Loneliness has also been associated with disorders such as depression, suicide, hostility, alcoholism and psychosomatic diseases (Kastenbaum 1979; McWhirter, 1990), which lead to a greater need for medical services (Lynch, 1977). Peplau and Perlman (1982) note such physical symptoms as a disturbance in a person's sleep and/or eating patterns, as well as headaches. Lonely people also commonly experience chronic fatigue, pain and tension (Berg, et al., 1981; Gerstein \& Tesser, 1987; Weiss, 1973; Williams, 1987). Lynch (1977) notes that chronic loneliness may even lead to serious cardiovascular illnesses and premature death.

Considering this discussion and considerations above, it is evident that faith necessitates thorough investigation as an important correlate of loneliness. The previously mentioned study by Le Roux (1998) on 100 third-year students, already showed a strong negative correlation between these two variables. However, as it was pointed out in that study, the sample was not representative of all third-year students on the campus of the University of the Orange Free State. Only psychology students took part in the investigation. The researcher therefore 
conducted the present much broader study to verify her previous findings. The primary purpose of this study therefore, is to investigate the importance of the Christian faith in the prediction of loneliness. A secondary goal is to determine whether biographical variables such as gender, age, church attendance, frequency of prayer, and Christian rebirth, can also be used to contribute to the prediction of loneliness. The main research hypothesis is thus that Christian faith as well as a weighted combination of certain biographical variables can be used in the prediction of loneliness.

\section{Method}

\section{The Sample}

The subjects consisted of 430 male and 570 female members from eight congregations of the Dutch Reformed Church (DRC) in Bloemfontein. These congregations were drawn randomly out of the total group of DRC congregations in Bloemfontein. In this way information was gathered from more than 3000 congregants. The sample was then reduced to 1000 by selecting every third questionnaire as part of the research group. Altogether 1021 questionnaires were drawn from the original sample, but 21 were incomplete or were completed incorrectly, and thus had to be removed. The average age of the subjects in this sample was 29 years.

\section{The procedure}

As part of their practical training in research, third year students registered for Psychology at the University of the Orange Free State were divided into teams to assist with the gathering of the data. They were given thorough prior training so that they would be able to carry out all aspects of the process correctly. Permission was then obtained from the ministers and church councils of the selected congregations in order to visit them during the morning service on a specified Sunday. After the service, those willing to complete the questionnaires remained behind in the church. The questionnaires were distributed amongst them, after which the necessary instructions were given in Afrikaans. The students offered their assistance where more information was required, and were continually present, in order to see to it that each subject completed the questionnaire independently.

The reason for gathering data from members of church congregations is, firstly, that morning services in Bloemfontein are normally attended by many members, and thus represent one of the greatest gathering points of people. Secondly, the members of each congregation normally come from all spheres of society, so that a selection could be made from a wide variety of professions. Furthermore, it is a fact that many people who attend services are not necessarily true believers. Many people attend church because they see it as their social gathering of the week (Sears et al., 1991), and because they want to conform to group norms.

\section{Measuring instruments}

Each person was given the following measuring instruments:

\section{- The Le Roux Loneliness Scale}

This questionnaire consists of 30 items, and has already been used in previous studies (Le Roux, 1992; Le Roux, 1998; Scholtz, 1995). Examples of items in the questionnaire were: "I grew up in a loving home" (Item 2); "I feel forgotten" (Item 19); "My friends make me happy" (Item 24) and "Nobody can help me" (Item 28). The respondents had to indicate to which degree they agree with each statement or not by marking one of four response categories, varying from always to never, with a cross. All fifteen negative items in the questionnaire have numerical values varying from 4 to 1 , while the positive items were numbered from 1 to 4 in the response categories. This means that should a subject obtained a high score this person can be regarded being lonely. Those with lower scores should be regarded as not being lonely. 
The reliability of the questionnaire has, in various studies, been calculated by Cronbach's alpha coefficient and has been reported to be 0.88 and 0.87 (Le Roux, 1992; Scholtz, 1995), while the internal validity has also been investigated and a correlation of $r_{p n}$ $=-0.6116$ was obtained between the positive and negative halves of the scale.

\section{- $\quad$ The Shepard Scale (Basset et al., 1981)}

This instrument was discussed fully in a previous article (Le Roux, 1998). It was designed to measure faith in Jesus Christ and consists of two components, viz. the cognitive component of faith, which measures the knowledge aspect of a person's Christian faith, and the walk component, which is designed to determine to what degree people practically live out their faith. The first component consists of 13 items, while the second consists of 25 . The highest score a person can obtain on the total scale is 152 points, and the lowest 38 . A high score is indicative of a Christian's strong faith in Jesus Christ, with a low score indicating the opposite.

Several studies have already indicated that the scale is reliable and valid for studies of this nature (Le Roux, 1998). A very recent study conducted by Raubenheimer (1997) found that the reliability for the knowledge component of the scale was 0.7674 , while the reliability of the walk component was 0.9237 , giving the total scale a reliability of 0.9254 .

\section{- Biographical questionnaire}

The biographical questionnaire consists of questions concerning the person's gender, age, church attendance, frequency of prayer, and whether they were "born again" or not. These details were included after a thorough study of the literature. An example of the questionnaire can be seen in the Appendix A.

\section{- $\quad$ Statistical techniques}

In order to determine the combination of biographical variables which correlate most highly with loneliness, use was made of a stepwise multiple regression analysis. Here the single variable which explains the greatest proportion of variance of loneliness is selected first. Further variables are only selected into the equation if their inclusion allows the equation to account for significantly more variance than the weighted combination of the already selected variables. Intercorrelations between the different variables were obtained through the use of Pearson's product-moment correlation. The level of significance was set at 0,01 .

\section{Results}

The reliability of the two measuring instruments was also investigated in this study, and the alpha coefficients obtained compared very well with the figures reported in previous studies. As far as the Le Roux Loneliness Scale is concerned, a reliability of 0.88 was obtained. The reliability for the total score of the Shepard Scale was 0.91. Again, this compares excellently with the results obtained in previous studies, as discussed above.

Table 1 shows the frequencies and percentages regarding the subjects' gender, age, frequency of prayer, church attendance and new birth.

From the table it can be seen that more women (57\%) than men (43\%) were included in this sample. Furthermore, it is evident that the largest percentage of people $(32.5 \%)$ fall in the age group of 20 to 24 years, with a further $25.1 \%$ falling between 35 and 40 years. As far as frequency of prayer is concerned, $74.1 \%$ reported that they pray to God daily, with 102 (or $10.2 \%)$ praying twice a week. It is also interesting to note that $62(6.2 \%)$ of the churchgoers pray only once a week; $36(3.6 \%)$ monthly, while $59(5.9 \%)$ reported that they never pray. 
Table 1: Frequencies and percentages regarding the biographical variables

\begin{tabular}{|c|c|c|}
\hline - Gender & $\mathbf{N}$ & $\%$ \\
\hline Male & 430 & 43 \\
\hline Female & 570 & 57 \\
\hline Total & 1000 & 100 \\
\hline - Age & $\mathbf{N}$ & $\%$ \\
\hline $15-19$ & 191 & 19.1 \\
\hline $20-24$ & 325 & 32.5 \\
\hline $25-29$ & 118 & 11.8 \\
\hline $30-34$ & 115 & 11.5 \\
\hline $35-40+$ & 251 & 25.1 \\
\hline Total & 1000 & 100 \\
\hline -Frequency of Prayer & $\mathbf{N}$ & $\%$ \\
\hline Daily & 741 & 74.1 \\
\hline 2 times a week & 102 & 10.2 \\
\hline weekly & 62 & 6.2 \\
\hline monthly & 36 & 3.6 \\
\hline never & 59 & 5.9 \\
\hline Total & 1000 & 100 \\
\hline - Church attendance & $\mathbf{N}$ & $\%$ \\
\hline More than once a week & 291 & 29.1 \\
\hline Once a week & 399 & 39.9 \\
\hline twice a month & 170 & 17.0 \\
\hline Once a month & 76 & 7.6 \\
\hline Never & 64 & 64 \\
\hline Total & 1000 & 100 \\
\hline - Born again & $\mathbf{N}$ & $\%$ \\
\hline Yes & 906 & 90.6 \\
\hline No & 94 & 9.4 \\
\hline Total & 1000 & 100 \\
\hline
\end{tabular}

Church attendance also delivered interesting results. Of the sample, the largest percentage (39.9\%) attended church once a week, and $29.1 \%$ more than once a week. Of the total group, $17 \%$ reported that they attend church twice a month, and $7.6 \%$ that they only attend church once a month. Interestingly enough 64 of the subjects (or 6.4\%) said that they never attend church, yet they were in church that specific morning. A large majority of the sample, reported being born again, while others did not.

In the following table, Table 2, the averages and standard deviations of the biographical variables can be found. The results are self-explanatory. 
Table 2: Averages and standard deviations for all the biographical variables

\begin{tabular}{|c|c|c|}
\hline Variable & $\bar{X}$ & $\mathbf{S}$ \\
\hline - Loneliness & 57.222 & 14.135 \\
\hline $\begin{array}{l}\text { Faith } \\
\text { cognitive componment } \\
\text { walk component } \\
\text { total score } \\
\end{array}$ & $\begin{array}{l}46.648 \\
82.354 \\
129.002\end{array}$ & $\begin{array}{l}5.026 \\
10.837 \\
14.482\end{array}$ \\
\hline - $\quad$ Gender & 1.570 & 0.495 \\
\hline - $\quad$ Frequency of prayer & 1.570 & 1.138 \\
\hline - $\quad$ Church attendance & 2.22 & 1.137 \\
\hline - $\quad$ Age & 2.910 & 1.484 \\
\hline - $\quad$ Christian rebirth & 1.090 & 0.292 \\
\hline
\end{tabular}

The intercorrelation matrix for all the variables is shown in Table 3.

From the table it is evident that faith correlates highly significantly with loneliness, and that the correlation coefficient is negative. This value (SS total score correlated with loneliness) is the highest of all the correlations, viz. -0.4010 . The negative coefficient means that the lower the faith score, the higher the loneliness score, and vice versa. In other words, a person with a strong faith in Jesus Christ is less likely to be lonely than somebody whose faith is not as strong. In keeping with the total score, both components of the SS reflect an inverse relationship. The second highest correlation is that between loneliness and the walk component (-0.3790), while the cognitive component of faith $(-0.3382)$ delivers the third strongest correlation coefficient. As far as the walk component is concerned, the implication is that the more Christians succeed in living out their faith in a practical manner, the less likely they are to be lonely, with the opposite also being true. The inverse relationship between the cognitive component and loneliness shows that subjects with a good knowledge of their Christian faith are less lonely than those subjects whose knowledge of the Christian faith is not so good, and vice versa.

The other variables correlating highly with loneliness are frequency of prayer (0.2964), being born again (0.2256) and church attendance (0.2119). According to the coding shown in Table 1, the interpretation of these results are as follows: the more a person prays, the less likely that person is to be lonely, and the less people pray, the more likely they are to be lonely; People who have been born again through the power of the Holy Spirit, are less lonely than people who say that they have not yet been born again; Christians who regularly attend church are less lonely than people who do not attend church. Furthermore, it can be seen that gender correlates significantly with loneliness, with a negative correlation coefficient of $-0,0779$. When seen in the light of the coding of the variables (see Table 1) this indicates that the women in this study were lonelier than the men.

Table 3 further shows that some of the intercorrelations are relatively high. This was, however, expected simply because these variables are dependent on each other. In this manner faith's walk component correlates 0.9618 with the total score of the scale, while the cognitive component correlates 0.8075 with the total score. Furthermore, it can be seen that the intercorrelations between faith, church attendance, prayer and being born again, are highly significant. This is as a result of the interrelatedness of these variables. Another variable which correlates highly with faith, but not with loneliness, is age (0.1364). This would seem to indicate that young people's faith is not as strong as for people in their higher age groups. 
Table 3: Intercorrelation matrix for all the variables

\begin{tabular}{|c|c|c|c|c|c|c|c|c|c|}
\hline & Loneliness & Faith $_{1}$ & Faith $_{2}$ & Faith $_{3}$ & Gender $_{\text {B1 }}$ & $\mathrm{Age}_{\mathrm{B} 2}$ & $\begin{array}{l}\text { Church } \\
\text { Atten- } \\
\text { dance }_{B 3}\end{array}$ & Prayer $_{B 4}$ & Rebirth $_{\mathrm{B} 5}$ \\
\hline Loneli-ness & 1.0000 & & & & & & & & \\
\hline Faith $_{1}$ & $-0.3382^{* * *}$ & 1.0000 & & & & & & & \\
\hline Faith $_{2}$ & -0.3790 *** & $0.6153^{* * *}$ & 1.0000 & & & & & & \\
\hline Faith $_{3}$ & $-0.4010 * *$ & $0.8075^{* * *}$ & $0.9618^{* *}$ & 1.0000 & & & & & \\
\hline Gender $_{B 1}$ & $-0.0779 *$ & 0.0179 & $0.0711^{*}$ & 0.0594 & 1.0000 & & & & \\
\hline $\mathrm{Age}_{\mathrm{B} 2}$ & 0.0495 & $0.1364^{* * *}$ & $0.0793^{*}$ & $0.1067^{* *}$ & -0.0050 & 1.0000 & & & \\
\hline $\begin{array}{l}\text { Church } \\
\text { Attendance }{ }_{B} 3\end{array}$ & $0.2119 * *$ & $-0.3233^{* *}$ & $-0.4116^{* * *}$ & $-0.4202 * *$ & -0.0429 & $-0.0783^{*}$ & 1.0000 & & \\
\hline Prayer $_{\text {B4 }}$ & $0.2964^{* *}$ & -0.2866 *** & $-0.3964 * *$ & $-0.3961 * *$ & $-0.1419 * *$ & 00.0419 & $\begin{array}{l}0.3551 * \\
*\end{array}$ & 1.0000 & \\
\hline Rebirth $_{B 5}$ & $0.2256^{* * *}$ & $-0.3894 * *$ & $-0.4414 * *$ & $-0.4655 * *$ & -0.0109 & 0.0080 & $0.3077 * *$ & $0.4924^{* * *}$ & 1.0000 \\
\hline
\end{tabular}

* $\mathrm{p} \leq 0.05$

$* * \mathrm{p} \leq 0.01$

Table 4 contains the results of the multiple regression analyses to predict loneliness by means of the Christian faith and certain biographical variables. It contains the details concerning the regression coefficient (beta), the standard error of measurement, the proportion of variance which the regression equation explained, the t-value, the F-value and, lastly, the level of significance.

Table 4: Multiple regression analysis to predict loneliness by means of Christian faith and biographical variables

\begin{tabular}{|l|l|l|l|l|}
\hline Variable & Beta & SE Beta & $\mathbf{R}^{2}$ & t-value \\
\hline Faith $(1,2,3)$ & -0.4010 & 0.0283 & 0.1608 & $-13.828 * * *$ \\
\hline Prayer & 0.1631 & 0.3873 & 0.1832 & $5.233 * * *$ \\
\hline Age & 0.0933 & 0.2729 & 0.1918 & $3.257 * *$ \\
\hline
\end{tabular}

F-value: $78.8046 * * *$

$$
\begin{aligned}
& * * \mathrm{p} \leq 0.001 \\
& * * * \quad \mathrm{p} \leq 0.000
\end{aligned}
$$

From the table it can be seen that the following variables were selected, in order: first the total faith score as the main variable, which includes both the cognitive and walk components. Secondly the frequency of prayer of the individual was added to the equation, while the age of the person was selected as the last variable. None of the other variables, viz. church attendance, being born again, or gender could account for a significant proportion of the variance of loneliness. Although their correlations with loneliness, as well as their intercorrelations with each other were highly significant, they could not add further to the prediction of loneliness.

Faith is, according to Table 4, a highly significant negative predictor of loneliness, accounting for $16.08 \%$ of the variance of loneliness. Prayer was also included in the 
regression equation, explaining $2.24 \%$ of the variance. Finally, age was identified even though it was only responsible for nearly $1 \%$ of loneliness' variance.

The reason that prayer and age contributed so little to the regression equation is that, although they correlated highly with loneliness, they also correlated highly with faith, and thus could contribute little unique variance to the equation.

\section{Discussion}

The results of this study provide support for the salience of faith in the experience of loneliness. Those subjects who indicated that their faith in Jesus Christ is very strong were less likely to be lonely than those whose Christian faith was not as strong. This measurement of Christian faith consisted of two components, viz. the practical exercising of their faith, and their cognitive knowledge about the Christian faith. These results compliment the research findings of Le Roux (1998) and Allport and Ross (1967), who determined that individuals with a high score on a measurement of Christian faith have lower loneliness scores.

The results are also in agreement with the opinions of many authors (Couwenberg, 1959; Duvenhage, 1975; Gaev, 1976; Moberg \& Brusek, 1978; Paloutzian \& Ellison, 1982; Zimbardo, 1979). The greatest problem with lonely people is the severance of their vertical relationship with God through faith in Jesus Christ. They have become estranged from the root of their existence: God. They are not involved in an intimate and personal relationship with Him, and can thus never come to full self-realisation and growth. As a result of this they feel lonely and rejected, and they experience feelings of emptiness and shallowness in a rapidly disintegrating world filled with animosity. They are continually seeking to find meaning and depth in their existence.

The next variable which was selected into the regression equation is the frequency of prayer of the individual, accounting for $2.24 \%$ of the variance. None of the other variables, barring age, which correlated highly with faith, but not loneliness, were included in the regression equation. This finding is in agreement with the view of MacArthur (1995), viz. that prayer dispels loneliness. Even if believers should be forsaken by their own family, friends, or even their fellow-believers, they will never be rejected by God and, accordingly, they will never be alone again. God has laid claim to their lives, and lives in them personally through His Spirit. His presence is all that they would ever need: He comforts them, teaches and guides them in the truth, and leads them on the right path, so that they can arrive at the goal for which He created them. Even should they pass through the most trying circumstances, $\mathrm{He}$ is with them; when they feel broken and heartsore, He is the ointment for their wounds; when they are afraid, He holds them tight in His mighty right hand. In Isaiah 43:2-3 He says: "When you pass through the waters, I will be with you; and when you pass through the rivers, they will not sweep over you. When you walk through the fire, you will not be burned; the flames will not set you ablaze. For I am the Lord, your God, the holy one of Israel, your Saviour." Christian believers know the promises of God and live daily from those promises. That is why prayer is such an important desire of their hearts (MacArthur, 1995). They are in continual communication with Him, and thus abide in an intimate and personal relationship with the Almighty God.

Even though faith may be a major predictor of loneliness, it would be presumptuous to claim it as the sole predictor of loneliness. Loneliness is a complex phenomenon, one in which a multitude of causative factors conspire to create the intensity of conflicts and emotions that is loneliness. Nevertheless, faith, while not being the sole predictor of loneliness, is a major factor in determining the individual's experience of loneliness, and it 
may even be that in some cases the person's faith is strong enough to allay all the other factors which would have caused loneliness.

The last variable added to the regression equation, is age. As already been noted, age does not correlate significantly with loneliness, but with faith. It is understandable that those people in the higher age groups will have a stronger faith in Jesus Christ than those who were younger. It is this correlation which explains the significance of age in the regression equation. The probable reason for the correlation between age and faith is that just as people are behaviourally on different levels of development, so also they find themselves on different levels of faith development. Younger people are still in the process of determining their identity, which is an important developmental task of adolescence and early adulthood. Along with this younger people are still developing relationships with other people, and also with God. Younger people are still in the process of determining whom they will relate to, and who and what they will believe in. Younger people still have many questions about life in general, and religion specifically, questions which their elders have already had ample time to work through satisfactorily. Older people thus have a greater base of experience on which to rest their faith, and their faith is more stable, more settled. The Word of God instructs parents to instruct and admonish their children in the ways of the Lord, implying that their faith in Jesus Christ develops as their knowledge of the Word develops.

The present study has a number of inadequacies that future research might ameliorate. In the first place, the study was conducted amongst churchgoers who also subscribe to the Christian faith. This researcher chose this population because many people attend morning services in Bloemfontein, and a large number of people from all ages and occupations could be included in the study. Furthermore, it must be remembered that South Africa is one of the largest Christian nations in the world, and that $78 \%$ of the total population are Christians. It could thus be difficult to launch a study here amongst people who have not yet being exposed to Christian values and norms. Secondly, this researcher accepts that loneliness is probably experienced differently in various cultures. For this reason repetition of this study amongst people of other cultures is advisable.

\section{Conclusion}

Up to now, the Christian faith has been underestimated by psychological researchers and practitioners as an important determinant in the study of emotional conditions such as loneliness, and has, as a result, practically being ignored. This study has clearly shown the salience of the Christian faith, as well as continued communication with God through means of prayer, as main variables in the study of loneliness. In a dark, rapidly disintegrating world, it is still God's desire that believers would understand Him and know Him (Isaiah 9:23-24). This is the essence of being a Christian. The apostle John (17:3) writes: "This is eternal life that they may know Thee, the only true God and Jesus Christ whom Thou has sent" (emphasis added). However, when people think of eternal life with God, they think of a life that goes on forever. However, the Scriptures clearly indicate that it entails much more than this, it is a quality of life for the person who knows God (MacArthur, 1993). Unfortunately, many lonely people today have placed their focus on the temporary things of the world, and have exchanged the priviledge of knowing God for that which is mundane. The most certain manner in which they can expel loneliness, is to learn to know God and to progressively become more deeply and intimately acquainted with Him, receiving and recognizing and understanding the wonders of His person more strongly and more clearly.

Ferguson (1987, p. 4) writes in this regard: 
Do we consider knowing God to be the greatest treasure in the world, and by far our greatest privilege? If not, we are but pygmies in the world of the Spirit. We have sold our Christian birthright for a mess of pottage, and our true Christian experience will be superficial, inadequate, and tragically out of focus.

Psychologists have much field to gain after decades of neglecting emotional behaviour, and underestimating and ignoring the spiritual side of human existence. According to Baxter (cited in Thomas, 1977) hundreds of serious physical and psychological illnesses wait on those who are out of focus and harmony with God. Overfull prisons, hospitals and psychiatric institutions provide clear evidence for this. In many instances there are also indicators of lives without true joy, lives which lack joy because they are lacking in a loving, intimate fellowship with God through faith in Jesus Christ. 


\section{REFERENCES}

Allport, GW \& Ross, JM 1967. Personal religious orientation and prejudice. Journal of Personality and Social Psychology, 5, 432-443.

Barretta,, D, Dantzler D and Kayson, W 1995. Factors related to loneliness. Psychological Reports, 76, 827-830.

Bassett, RL, Sadler, RD, Kobischen, EE, Skiff, DM, Merrill, IJ, Atwater, BJ and Livermor, PW, 1981. The Shepherd Scale: Separating the sheep from the goats. Journal of Psychology and Theology, 9, 335-351.

Berg, S, Mellström, D, Persson, G and Svanberg, A 1981. Loneliness in the Swedish Aged. Journal of Gerontology, 36, 342-349.

Bolea, AS 1986. Treating loneliness in children. In Natale, SM (ed.), Psychotherapy and the lonely patient, New York: Hayworth.

Borys, S, and Perlman, D 1985. Gender differences in loneliness. Personality and Social Psychology, 11(1), 63-74.

Brage, D, Meredith, W, and Woodward, J 1993. Correlates of loneliness among midwestern adolescents. Adolescence, 28(111), 685-693.

Cheek, JM and Busch, CM 1981. The influence of shyness on loneliness in a new situation. Personality and Social Psychology Bulletin, 7(4), 572-577.

Clay, R 1996. Psychologists' faith in religion begins to grow. APA Monitor, $27,1$.

Couwenberg, SW 1959. Die vereenzaming van de moderne mens. Gravenhage: NV Uitgeversmaatschappij Pax.

Cruz, N 1983. Lonely, but never alone. Goodwood: Lux Verbi.

Cutrona, CE 1982. Transition to college: Loneliness and the process of social adjustment. In Peplau, LA \& Perlman, D (eds), Loneliness: A sourcebook of theory, research, and therapy (pp. 291-309). New York: Wiley.

De Beer, E 1992. Eensaamheid en intimiteit by getroude studente in vroeë volwassenheid. Unpublished Master's dissertation, University of the Free State, Bloemfontein.

Diamant, L and Windholz, G 1981. Loneliness in college students: Some theoretical, empirical, and therapeutic considerations. Journal of College Student Personnel, 11, 515-522.

Dufton, B 1984. Inter-relationships between loneliness and religiosity. Unpublished doctoral dissertation. University of Manitoba, Winnepeg.

Duvenage, SCW June 1975. Die vereensaming of vervreemding van die moderne mens. Potchefstroom: Institute for the enhancement of Calvinism.

Ellison, CW 1978. Loneliness: A social-developmental analysis. Journal of Psychology and Theology, 6, 3-17.

Ferguson, S 1987. A Heart for God. Carlisle, Pa.: The Banner of Truth.

Ferns, I 1988. Vereensaming, lokus van kontrole en die selfkonsep tydens vroeë volwassenheid. Unpublished Master's dissertation, University of South Africa, Pretoria.

Ferns, I 1991. Determinante van vereensaming tydens vroeë volwassenheid. South-African Journal of Psychology, 21(1), 54-60.

Gaev, DM 1976. The psychology of loneliness. Chicago: Adams.

Gerstein, LH and Tesser, A 1987. Antecedents and responses associated with loneliness. Journal of Social and Personal Relationships, 4, 329-363.

Goldenberg, S and Perlman, D 1984. Social relations and loneliness during adolescence. Manuscript submitted for publication. 
Hansson, RO and Jones, WH 1981. Loneliness, cooperation and conformity among American undergraduates. The Journal of Social Psychology, 115, 103-108.

Hojat, M 1982. Loneliness as a function of selected personality variables. Journal of Clinical Psychology, 38(1), 137-141.

Janse van Rensburg, K 1991. Eensaamheid onder tieners in Oos-Londen. Unpublished Master's dissertation, University of the Free State, Bloemfontein.

Jones, SL 1994. A constructive relationship for religion with the science and profession of psychology. American Psychologist, 49(3), 184-199.

Jones, WH, Sansone, C and Helm, B 1983. Loneliness and interpersonal judgements. Personality and Social Psychology Bulletin, 9(3), 437-441.

Kastenbaum, R 1979. Humans developing. A lifespan perspective. Boston: Allyn and Bacon.

Le Roux, A 1992. Loneliness in teenagers: A study of this phenomenon in Bloemfontein. Unpublished manuscript, Bloemfontein.

Le Roux, A 1998. The relationship between loneliness and the Christian faith. South African Journal of Psychology, 28(3), 174-181.

Le Roux, A and De Beer, E 1994. Eensaamheid en intimiteit onder getroude studente in vroeë volwassenheid. S.A. Journal of Psychology, 24(2), 53-61.

Lloyd-Jones, M 1979. Studies in the Sermon on the Mount. Grand Rapids: Eerdmans.

Lynch, JJ 1977. The broken heart. The medical consequences of loneliness. New York: Basic Books.

MacArthur, J 1991. Volkome in Christus. Cape Town: Struik Christelike Boeke.

MacArthur, J 1993. God. Illinois: Victor Books.

MacArthur, J 1995. Alone with God. Illinois: Victor Books.

McGraw, JG 1992. God and the problem of loneliness. Religious Studies, 28, 319-346.

McWhirter, BT 1990. Factor Analysis of the Revised UCLA Loneliness Scale. Current Psychology: Research \& Reviews, 9(1), 56-68.

Medora, N and Woodward, JC 1986. Loneliness among adolescent college students at a midwestern university. Adolescence, 27(82), 391-402.

Moberg, DO and Brusek, PM 1978. Spiritual well-being: A neglected subject in quality of life research. Social Indicators Research, 5, 303-323.

Moore, JA 1972. Loneliness: Personality, self-discrepancy and demographic variables. Dissertation Abstracts International, 34(5), 2287B.

Moore, D and Schultz, NR 1983. Loneliness of adolescence: Correlates, attributes and coping. Journal of Youth and Adolescence, 12(2), 95-100.

Natale, SM 1986. Loneliness and the aging client. In Natale, SM (ed.), Psycotherapy and the lonely patient. New York: Haworth.

Odendal, A 1985. 'n Persoonlikheidsbeeld van eensame en nie-eensame eerstejaar-universiteitstudente. Unpublished Master's dissertation, Rand Afrikaans University, Johannesburg.

Paloutzian, RF and Ellison, CW 1982. Loneliness, spiritual well-being and the quality of life. In Peplau, LA \& Perlman, D (eds.). Loneliness: A sourcebook of current theory, research and therapy (pp. 229-237). New York: Wiley.

Parlee, MB 1979, October. The friendship bond. Psychology Today, 113, 43-54.

Peplau, LA and Perlman, D 1982. Perspectives on loneliness. In Peplau, LA \& Perlman, D (eds). Loneliness: A sourcebook of current theory, research and therapy (pp. 1-18). New York: Wiley.

Pontzetti, JJ 1990. Loneliness among college students. Family Relations, 39, 336-340. 
Pretorius, TB 1993. The metric equivalence of the Revised UCLA Loneliness Scale for a sample of South African Students. Educational and Psychological Measurement, 53, 232-236.

Quellet, R and Joshi, P 1986. Loneliness in relation to depression and self-esteem. Psychological Reports, 58, 821-822.

Raubenheimer, JE 1997. Love styles, Christian faith and religious orientation of a group of students from the UOFS. Unpublished Master's dissertation, University of the Free State, Bloemfontein.

Rokach, A and Brock, H 1996. The causes of loneliness. Psychology: A Journal of Human Behavior, 1-10.

Rokach, A and Brock, H 1997. Loneliness: A multidimensional experience. Paper presented at the Ontario University, Canada..

Rubenstein, CM amd Shaver, P 1982. The experience of loneliness. In Peplau, LA \& Perlman, D. (eds), Loneliness: A sourcebook of current theory, research and therapy (pp. 206223). New York: Wiley.

Scholtz, E. (1995). Eensaamheid onder Vista-studente in Bloemfontein. Unpublished Master's dissertation, University of the Free State, Bloemfontein.

Sears, DO, Peplau, LA and Taylor, SE 1991. Social psychology (7th ed.). Englewood Cliffs, NJ Prentice-Hall.

Solano, CH, Batten, PG and Parish, EA 1982. Loneliness and patterns of self-disclosure. Journal of Personality and Social Psychology. 43(3), 524-531.

Sullivan, HS 1953. The interpersonal theory of psychiatry. New York: Norton.

Sundberg, CP 1988. Loneliness: Sexual and racial differences in college freshman. Journal of College Student Development, 29, 298-305.

Taylor, SE, Peplau, LA and Sears, DO 1994. Social psychology (8th ed.). Englewood Cliffs, NJ Prentice-Hall.

Thomas, IDE 1977. A Puritan Golden Treasury. Edinburgh: Banner of Truth.

Tozer, AW 1984. The knowledge of the Holy. Eastbourne: Kingsway Publications.

Weiss, RS 1973. Loneliness: The experience of emotional and social isolation. London: MIT Press.

Weiss, RS 1989. Reflections on the present state of loneliness research. In Hojat, M \& Crandall, R, (eds.), Loneliness: Theory, research and applications (pp. 71-80). London: Sage.

Williams, LM 1987. A concept of loneliness in the elderly. Journal of the American Geriatrics Society, 26(4), 183-187.

Williams, JG and Solano, CH 1983. The social reality of feeling lonely: Friendship and reciprocation. Personality and Social Psychology Bulletin, 9, 237-242.

Woodward, J and Frank, B 1988. Rural adolescent loneliness and coping strategies. Adolescence, 23, 559-565.

Young, JE 1982. Loneliness, depression and cognitive therapy: Theory and application. In Peplau, LA \& Perlman, D (eds.), Loneliness: A sourcebook of current theory, research and therapy (pp. 379-405). New York: Wiley.

Zimbardo, PG 1979. Psychology and life. Glenview, Ill.: Scott, Foresman. 


\section{APPENDIX A BIOGRAPHICAL QUESTIONNAIRE}

Please answer all of the undermentioned questions on your own. Please be totally honest. Encircle the relevant number in the block which corresponds to your choice.

1. Gender: Male

Female

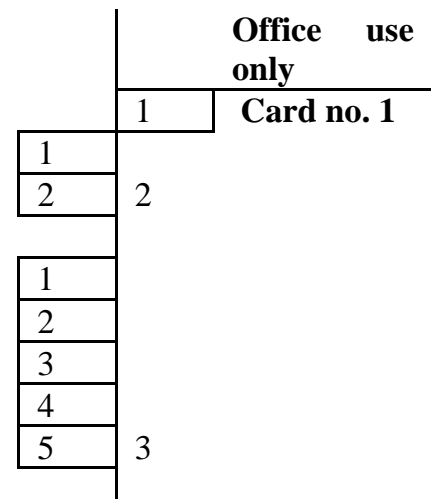

3. How many times have you

attended a church service in the last month?

More than once a week

Once a week

Twice a month

Once a month

Never

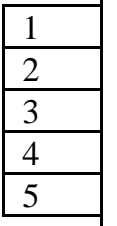

4. How frequently do you engage in personal prayer?

Daily

Twice a week

Weekly

Monthly

Never

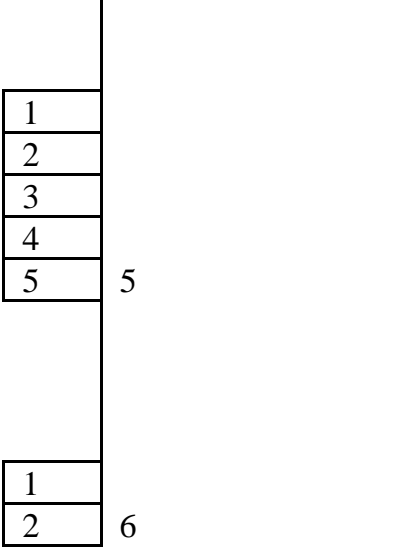

